\title{
Comunicação
}

[Communication]

\section{Prevalência de anticorpos contra o vírus da língua azul em bovinos e ovinos do sudoeste e sudeste do Rio Grande do Sul}

[Bluetongue virus antibodies in cattle and sheep in southwest and southeast regions of Rio Grande do Sul, Brazil]

\author{
J.R.R. Costa ${ }^{1}$, Z.I.P. Lobato ${ }^{2}$, G.P. Herrmann ${ }^{3}$, R.C. Leite ${ }^{2}$, J.P.A. Haddad ${ }^{2}$ \\ ${ }^{1}$ Médico veterinário autônomo \\ ${ }^{2}$ Escola de Veterinária - UFMG \\ Caixa Postal 567 \\ 30123-970 - Belo Horizonte, MG \\ ${ }^{3}$ Universidade Federal de Santa Maria - Santa Maria, RS
}

A língua azul (LA) é uma doença viral, não contagiosa, transmitida por mosquitos do gênero Culicoides sp. Todos os ruminantes domésticos e selvagens são susceptíveis à infecção pelo vírus da língua azul (VLA), porém a ocorrência da doença clínica tem sido demonstrada principalmente nos ovinos. O VLA é membro do gênero Orbivirus e da família Reoviridae e, até hoje, 24 sorotipos foram identificados em diversos países do mundo, localizados nas áreas tropicais e subtropicais.

De acordo com a Organização Internacional de Epizootias (OIE), a LA é uma doença notificável, cujo impacto econômico decorre não apenas das perdas diretas nos rebanhos afetados, mas também das restrições econômicas impostas por países importadores.

A primeira evidência do VLA no Brasil foi descrita por Silva (1978), que relatou a presença de anticorpos fixadores de complemento em bovinos e ovinos em São Paulo. A partir daí, vários inquéritos sorológicos realizados no território brasileiro em bovinos, caprinos, ovinos e bubalinos, por meio da técnica de imunodifusão em gel de ágar (IDGA), indicaram que o vírus está amplamente distribuído em todas as regiões testadas (Lobato,1999; Laender, 2002).
Condições de temperatura e umidade na maior parte do país favorecem a multiplicação e a manutenção dos vetores, o que torna a doença endêmica e com alta prevalência de animais soropositivos e sintomatologia clínica rara. Sabese que parte da população de ruminantes é imune à infecção pelos sorotipos presentes na área (Lobato, 1996).

Apesar da importância do Rio Grande do Sul (RS) como criador de bovinos e ovinos, poucos dados sobre a LA estão disponíveis para esse estado. Este trabalho teve como objetivo verificar a soropositividade para o VLA em bovinos e ovinos nas mesorregiões Sudoeste e Sudeste do Rio Grande do Sul .

A região estudada é formada por 35 municípios, onde se concentram os maiores criatórios de ovinos do $\mathrm{RS}$ (74,6\% do número total de ovinos do estado). O número de amostras de soros de ovinos e bovinos foi calculado de acordo com os procedimentos recomendados pelo Centro Panamericano de Zoonoses (Bioestatística..., 1979), por conglomerados, com prevalência esperada de $5 \%$ para ovinos e $5 \%$ para os bovinos, com grau de confiança de $90 \%$ e erro amostral de 20\%. Como universo amostral, coletaram-se, em 1999, 1331 soros de ovinos e

Recebido em 09 de maio de 2005

Aceito em 22 de agosto de 2005

*Autor para correspondência (corresponding author)

E-mail: ziplobat@vet.ufmg.br

Apoio: FAPEMIG/CNPq 
1272 soros bovinos em 18 municípios. Foram representados 135 estabelecimentos para ovinos e 128 para bovinos. Nos municípios que apresentaram mais de um estabelecimento, as coletas obedeceram a uma distribuição geográfica geométrica de quadrantes proporcionais, sorteando-se as propriedades por conglomerados. As amostras foram estratificadas segundo a composição do rebanho em: ovinos (90\% ovelhas, $10 \%$ de carneiros) com idade superior a um ano, e bovinos (90\% de vacas e $10 \%$ de touros) com idade superior a 2,5 anos. Após a coleta do sangue, o soro obtido foi aliquotado e armazenado $\mathrm{a}-20^{\circ} \mathrm{C}$ até o momento de sua utilização.

Para detecção de anticorpos precipitantes contra o vírus da língua azul, foi utilizada a técnica de IDGA, segundo Costa (1999).

Apenas uma propriedade $(0,74 \%)$, localizada no município de São Borja, apresentou dois ovinos positivos, o que significa $0,16 \%$ de prevalência em relação ao total de ovinos estudados. Das propriedades amostradas para bovinos, duas foram positivas $(1,6 \%)$, sendo uma localizada em Santana da Boa Vista, com dois bovinos positivos, e uma em São Borja, com seis bovinos positivos. Isso representou $0,60 \%$ de prevalência considerando-se o total de bovinos estudados.

Os resultados indicam baixa prevalência de anticorpos contra o VLA em ovinos e bovinos, mas mostram que há o vetor Culicoides sp, e que a circulação viral ocorre mesmo em baixa escala.

Quando comparada a outras regiões do Brasil, a prevalência encontrada no RS foi mais baixa, provavelmente atribuída às condições climáticas menos favoráveis para a multiplicação do vetor. No RS, o verão é caracterizado por temperaturas médias que oscilam entre $20^{\circ} \mathrm{C}$ e $40^{\circ} \mathrm{C}$, e o inverno por média de $10^{\circ} \mathrm{C}$ a $15^{\circ} \mathrm{C}$ (Anuário..., 1993).

Estudos realizados em bovinos em várias regiões brasileiras demonstram soroprevalência variando de 89 a 16\%. (Lobato,1999). Para os ovinos, poucos estudos estão disponíveis, apesar de ser essa a espécie cujos prejuízos econômicos são mais significativos. Recentemente foi estabelecida a prevalência média de $58 \%$ para o VLA nessa espécie no estado de Minas Gerais (Lobato et al., 2001; Gouveia et al., 2003). No
RS poucos estudos são encontrados e não há informações sobre a doença em ovinos. Cunha et al. (1987) testaram 409 soros de bovinos e encontraram $1,2 \%$ de animais soropositivos, sinalizando que a distribuição do vírus nesse estado era mais baixa do que a encontrada em outros estados do Brasil, observação confirmada neste trabalho.

O tipo de criação predominante neste estudo foi o de propriedades com grandes extensões de terra, em cujos campos os animais eram mantidos na maior parte do tempo, caracterizando o sistema de criação extensiva. A propriedade com bovinos e ovinos soropositivos, no município de São Borja, tinha como principal atividade a produção leiteira, onde os animais eram criados em sistema semi-intensivo. Nela conviviam bovinos e ovinos sob o mesmo manejo. Observou-se também alta prevalência de terrenos mistos e alagadiços, associada à temperatura que variou de 13 a $35^{\circ} \mathrm{C}$.

O fato de ter sido encontrado grande número de animais soronegativos nas regiões estudadas é preocupante, pois sabe-se que pequenas mudanças climáticas em regiões limítrofes podem resultar em aumento na taxa de transmissão, pelo aparecimento de vetores. É importante lembrar que o trânsito pode trazer animais virêmicos, introduzindo novos sorotipos na região.

O IDGA para o VLA tem sido um dos testespadrão preconizados pela OIE para certificação de animais com fins de trânsito internacional de ruminantes desde 1982 (Office..., 2003). Ele apresenta uma desvantagem que é a possibilidade de ocorrer reação cruzada com outros orbivírus. Contudo, pela metodologia utilizada, não foi possível afirmar se houve ou não esse tipo de reação nos animais soropositivos.

Apesar de a presença do vírus no Brasil já ser conhecida desde 1978, as informações sobre os sorotipos aqui existentes e a sua distribuição são muito precárias. Alguns estudos realizados a partir da soroneutralização cruzada de soros positivos no teste de IDGA indicaram que é possível que os sorotipos 1, 2, 4, 6, 10, 12, 13, 14, 17 e 19 estejam presentes no país (Cunha, 1990), porém, até o momento, apenas duas amostras foram isoladas e sorotipificadas no Brasil, os sorotipos 4 e 12 (Groocock e 
Campbell, 1982; Clavijo et al., 2002). Este último foi isolado em surto com alta mortalidade que acometeu ovinos e caprinos no estado do Paraná, no município de Campo Tenente em 2001 (Clavijo, 2002).

A falta de conhecimento dos sorotipos existentes no Brasil e a sua distribuição nos diferentes estados dificultam o controle e a adoção de medidas que evitem a introdução de novos sorotipos no país ou em áreas específicas. Com base nos dados desta pesquisa, observa-se que a necessidade de cumprir as regras de importação e de observar os cuidados na introdução de animais vivos no RS constitui um imperativo.

Palavras-chave: bovino, ovino, língua azul, Rio Grande do Sul

\begin{abstract}
It was studied bluetongue virus antibodies prevalence for sheep and cattle in Southwest and Southeast regions of Rio Grande do Sul State. A total of 2613 serum samples (1272 bovine and 1341 ovine) were tested by agar gel immunodiffusion. Eight bovine and two ovine samples were positive meaning a prevalence of $0.63 \%$ and $0.15 \%$, respectively. These results show that most of animals in these regions are negative to bluetongue.
\end{abstract}

Keywords: bovine, ovine, bluetongue, Rio Grande do Sul

\section{REFERÊNCIAS BIBLIOGRÁFICAS}

ANUÁRIO ESTATÍSTICO DO BRASIL. Rio de Janeiro, v.53, p.1-1/ 8-30, 1993.

BIOESTATISICA: procedimientos para estudios de prevalencia por muestreo. Buenos Aires: Organizacion Panamericana de la Salud, n.18, 1979.

CLAVIJO, A.; SEPULVEDA, L.; RIVA, J. et al. Isolation of bluetongue virus serotype 12 from an outbreak of the disease in South America. Vet. Rec., v.7. p.301-302, 2002.

COSTA, J.R.R. Produção e padronização de antígeno para lingua azul e prevalência nas mesorregiões Sudoeste e Sudeste do Rio Grande do Sul. 1999. 55f. Dissertação (Mestrado) - Escola de Veterinária, Universidade Federal de Minas Gerais, Belo Horizonte.

CUNHA, R.G., Anticorpos neutralizantes em soros de ruminantes domésticos do Brasil frente aos diferentes sorotipos do vírus da língua azul. Rev. Bras. Med. Vet., v. 12 , p. $3-7,1990$

CUNHA, R.G.; SOUZA, D.M.; PASSOS, W.S. Anticorpos para o vírus da língua azul em soros de bovinos dos estados de São Paulo e da região sul do Brasil. Rev. Bras. Med. Vet., v.6, p.121-124, 1987.

GOUVEIA, A.M.G.; LIMA, A.F.; LOBATO, Z.I.P. et al. Língua azul em ovinos e caprinos em Minas Gerais. In: CONGRESSO LATINO-AMERICANO DE BUIATRIA, 11.; CONGRESSO BRASILEIRO DE BUIATRIA, 5.; CONGRESSO NORDESTINO DE
BUIATRIA, 3., 2003, Salvador. Anais... Salvador: SBB, 2003. p.51-52.

LAENDER, J.O. Lingua azul em rebanhos de ovinos e caprinos em três mesorregiões de Minas Gerais: análise de evidência clínica e sorológica e identificação de Culicoides sp. 2002. 92f. Dissertação (Mestrado) - Escola de Veterinária, Universidade Federal de Minas Gerais, Belo Horizonte.

LOBATO, Z.I.P. Língua azul: a doença nos bovinos. Rev. Bras. Reprod. Anim., v.23, p.515-523, 1999.

LOBATO, Z.I.P. Virus de língua azul: construção de recombinantes em vírus vaccinia e resposta imune. 1996. 200f. Tese (Doutorado)- Escola de Veterinária, Universidade Federal de Minas Gerais, Belo Horizonte.

LOBATO, Z.I.P.; BARCELOS, M.A.C.; LIMA, F. et al. Língua azul em ovinos e caprinos da região mineira da SUDENE. In: CONGRESSO BRASILEIRO DE BUIATRIA, 4., 2001, Campo Grande, MS. Anais... Campo Grande: SBB, 2001. p.165.

OFFICE INTERNATIONAL DES EPIZOOTIES. Disponível em: $<$ http://www.oie.int/eng/normes/mmanual/A_00030.ht m>. Acessado em: 16/05/2003.

SILVA, F.J.F. Relatório sobre estudos de ocorrência de língua azul em São Paulo. Brasília, 1978. Relatório da Comissão de Estudos - Ministério da Agricultura. Port. Min. $\mathrm{n}^{\circ} 150$, fevereiro, 1978). 